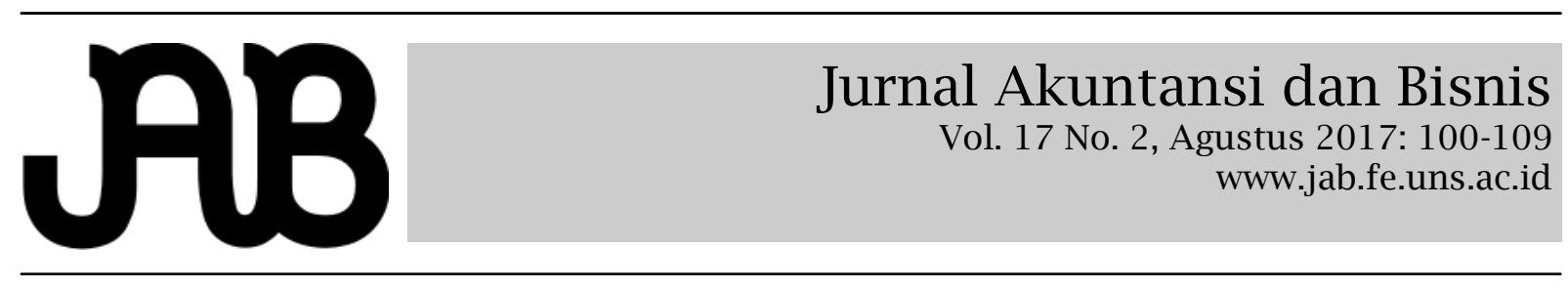

\title{
FAKTOR-FAKTOR YANG MEMPENGARUHI INTERNET FINANCIAL REPORTING PEMERINTAH DAERAH DAN IMPLIKASINYA TERHADAP AKUNTABILITAS LAPORAN KEUANGAN DAERAH
}

GUSTI INDIRA ALHAJJRIANA

WAHYUDIN NOR (wahyudinnor@unlam.ac.id)

RANO WIJAYA

Program Studi Akuntansi, Fakultas Ekonomi dan Bisnis, Universitas Lambung Mangkurat, Indonesia

\begin{abstract}
A B S T R A C T
This study aims to investigate the influence of local revenue, local expenditure, the number of legislative members, and the population number on internet financial reporting of local government; and the influence of local government's internet financial reporting on the accountability of local financial statement. The data of this research comprise 96 out of 32 provincial governments in Indonesia during 20122014. The analysis techniques used are logistic regression and ordinal logistic regression. The results of this study show that the local expenditure has influence on local government's internet financial reporting, while local revenue, the number of legislative members, and the population do not have influence on local government's internet financial reporting. Moreover, local government's internet financial reporting does not have influence on local financial statements.

Keywords: Internet Financial Reporting, Local Government, Accountability, Local Financial Statement
\end{abstract}

Penelitian ini bertujuan untuk mengetahui pengaruh pendapatan asli daerah, belanja daerah, jumlah anggota legislatif, dan jumlah penduduk terhadap internet financial reporting pemerintah daerah; dan pengaruh internet financial eporting pemerintah daerah terhadap akuntabilitas laporan keuangan daerah. Data penelitian ini terdiri dari 96 observasi dari 32 pemerintah provinsi di Indonesia selama tahun 2012-2014. Teknik analisis yang digunakan adalah regresi logistik dan regresi logistik ordinal. Hasil penelitian ini menunjukkan bahwa pengeluaran daerah berpengaruh terhadap internet financial reporting pemerintah daerah, sedangkan pendapatan daerah, jumlah anggota legislatif, dan populasi tidak berpengaruh terhadap internet financial reporting pemerintah daerah. Terlebih lagi, internet financial reporting pemerintah daerah tidak berpengaruh terhadap laporan keuangan daerah.

Kata kunci: Pelaporan Keuangan Internet, Pemerintah Daerah, Akuntabilitas, Laporan Keuangan Lokal

\section{PENDAHULUAN}

Memanfaatkan dan mengembangkan kemajuan teknologi informasi dalam menyalurkan informasi keuangan melalui situs resmi telah menjadi kewajiban pemerintah daerah. Hal ini termuat dalam Pasal 13 Peraturan Pemerintah No. 65 tahun 2010 tentang Sistem Informasi Keuangan Daerah yang merupakan perubahan Peraturan Pemerintah No. 56 tahun 2005 tentang Sistem Informasi Keuangan Daerah. Kewajiban pemerintah daerah untuk menyampaikan informasi turut ditegaskan melalui Undang-Undang No. 14 tahun 2008 tentang Keterbukaan
Informasi Publik yang menyatakan bahwa badan publik harus bersifat terbuka dan bertanggungjawab atas setiap informasi publik.

Seiring dengan dikeluarkannya undang-undang dan peraturan pemerintah, terkait penyampaian informasi kepada publik, pemerintah daerah seharusnya telah menggunakan internet sebagai media untuk menyampaikan laporan keuangan (Internet Financial Reporting) kepada masyarakat. Akan tetapi hasil penelitian Verawaty (2015) menunjukkan bahwa pada tahun 2012 hanya 37,93\% dari 87,9\% pemerintah provinsi di Indonesia yang ak- 
tif menggunakan e-government dan melakukan Internet Financial Reporting.

Pelaporan keuangan di internet (Internet Financial Reporting) sebenarnya merupakan cara pemda agar terlegitimasi. Legitimasi merupakan sebuah persepsi atau asumsi pihak eksternal bahwa suatu organisasi telah berjalan sesuai norma, aturan dan keyakinan yang berlaku di masyarakat (Suchman, 1995). Artinya, dengan adanya pelaporan keuangan di internet pemda dapat meyakinkan masyarakat dan stakeholders bahwa penyelenggaraan pemerintahan berjalan sesuai aturan yang berlaku. Selain itu, pelaporan merupakan salah satu tahap penting dalam akuntabilitas publik (Mahmudi, 2011).

Walaupun pemerintah daerah telah diwajibkan untuk menyampaikan informasi keuangan pada situs resmi, setiap pemerintah daerah memiliki alasan dan pertimbangan untuk melakukan publikasi atau tidak melakukan publikasi laporan keuangan melalui internet (Trisnawati \& Achmad, 2014). Ada beberapa faktor yang diduga dapat memengaruhi pemda melakukan pelaporan keuangan di internet.

Pendapatan daerah harus dipertangungjawabkan oleh pemda dalam laporan keuangannya sebagai bukti bahwa pendapatan daerah telah dikelola dengan baik sehingga pemda terlegitimasi. Artinya, semakin tinggi pendapatan suatu daerah seharusnya semakin mendorong keinginan pemda untuk mempublikasikan laporan keuangannya.

Penelitian Pratama, Sriwerastuti, dan Sujana (2015) menunjukkan bahwa belanja daerah berpengaruh terhadap pelaporan keuangan. Belanja daerah dapat menjadi faktor pendorong pemda untuk melakukan pelaporan keuangan di internet karena semakin besar belanja daerah menunjukkan bahwa pemda memberikan pelayanan yang baik dan fasilitas yang berkualitas kepada masyarakat (Pratama, Sriwerastuti, \& Sujana, 2015).

Penelitian Setyaningrum dan Syafitri (2012) menunjukkan bahwa jumlah anggota DPRD berpengaruh terhadap pengungkapan laporan keuangan. DPRD merupakan salah satu pengguna informasi sektor publik dan memiliki peran penting dalam melakukan pengawasan dan evaluasi terhadap kinerja pemda. Semakin besar jumlah anggota DPRD diharapkan berbanding lurus dengan kualitas laporan keuangan yang dilaporkan oleh pemda, sehingga dapat mendorong keinginan pemda untuk mempublikasikan laporan keuangan tersebut di internet.

Mengawasi kinerja pemda bukan hanya tugas dari legislatif, penduduk yang tinggal di daerah tersebut turut berperan dalam melakukan pengawasan terhadap kinerja pemda. Jumlah penduduk yang besar mengharuskan pemda menyediakan dana yang besar agar dapat menyampaikan informasi kepada publik. Penelitian Hilmi dan Martani (2012) menunjukkan bahwa jumlah penduduk berpengaruh terhadap pengungkapan laporan keuangan. Sebaliknya, penelitian Afryansyah dan Haryanto (2013) menunjukkan bahwa jumlah penduduk tidak berpengaruh.

Ketidakkonsitenan hasil penelitian sebelumnya dan sepengetahuan penulis penelitian tentang internet financial reporting masih terbatas. Hal ini memotivasi penulis untuk meneliti faktor-faktor apa saja yang mempengaruhi internet financial reporting pemda. Selain itu, penulis turut termotivasi untuk mengetahui bagaimana implikasi dari internet financial reporting pemda terhadap akuntabilitas Laporan Keuangan Daerah (LKD).

Berdasarkan penjelasan tersebut, penelitian ini bertujuan untuk mengetahui pengaruh pendapatan daerah, belanja daerah, jumlah anggota DPRD, dan jumlah penduduk terhadap internet financial reporting pemda serta untuk mengetahui pengaruh internet financial reporting pemda terhadap akuntabilitas Laporan Keuangan Daerah (LKD).

Penelitian ini diharapkan dapat menambah wawasan dan referensi dalam upaya pengembangan ilmu akuntansi sektor publik serta dapat menjadi referensi bagi akademisi yang ingin melakukan kajian terhadap internet financial reporting pemda. Selain itu, penelitian ini diharapkan dapat memotivasi dan menjadi bahan masukan pemda untuk menerapkan internet financial reporting. 


\section{T I N J A UA N PUS T A KA DA N PENGEMBANGAN HIPOTESIS \\ Teori Legitimasi}

Legitimasi merupakan sebuah persepsi atau asumsi sosial yang menunjukkan bahwa suatu organisasi atau entitas telah beroperasi sesuai dengan norma, nilai, atau keyakinan yang berlaku di masyarakat (Suchman, 1995). Legitimasi diperlukan bagi suatu organisasi dalam hal pengungkapan sosial dan lingkungan serta merupakan kerangka dasar dalam akuntabilitas pelaporan (Damaso \& Lourenco, 2001).

\section{Internet Financial Reporting Pemerintah Daerah}

Internet Financial Reporting atau Pelaporan keuangan di Internet merupakan suatu bentuk pertanggung-jawaban pemerintah atas anggaran yang telah dikelolanya melalui internet (Verawaty, 2015). Pelaporan keuangan pemerintah daerah merupakan media yang paling memenuhi aspek 3E (Efisiensi, Efektivitas, dan Ekonomi) untuk menyediakan dan menginformasikan mengenai laporan keuangan kepada semua stakeholder publik antara lain pemerintah pusat, pemerintah daerah lain, DPRD, BPK, analis ekonomi, investor, kreditor, donatur, dan rakyat (Verawaty, 2015). Menurut Government Finances Officers Association (2009) ada beberapa manfaat dari mempublikasikan informasi keuangan di situs resmi pemda seperti; Meningkatkan kepedulian pemda terhadap para pengguna informasi keuangan; Keteraksesan universal bagi seluruh pengguna informasi keuangan; Meningkatkan interaksi dengan pengguna informasi keuangan; Meningkatkan efisiensi dan menghemat biaya; dan Mengurangi penggunaan kertas yang berkelanjutan.

\section{Akuntabilitas Laporan Keuangan Daerah}

Akuntabilitas laporan keuangan daerah merupakan kewajiban pemerintah daerah untuk mempertanggungjawabkan dan melaporkan hasil proses akuntansi keuangan daerah yang berupa laporan keuangan atas pengelolaan sumber daya yang telah diberikan (Mahmudi, 2011;
Mahsun, Sulistiyowati, dan Purwanugraha, 2012). Salah satu proses atau tahap penting dalam akuntabilitas adalah proses akuntansi dan pelaporan karena akuntansi dan pelaporan merupakan dasar serta kekuatan utama yang memiliki pengaruh dalam pengambilan keputusan (Mahmudi, 2011).

\section{Pengembangan Hipotesis}

Kekayaan daerah merupakan indikator yang menentukan kesuksesan suatu daerah. Menurut Undang-Undang No. 17 tahun 2003, pendapatan daerah menambah kekayaan bersih daerah dan terdiri dari Pendapatan Asli Daerah (PAD), dana perimbangan, dan lain-lain pendapatan daerah yang sah. Semakin tinggi pendapatan daerah yang diperoleh oleh pemda artinya semakin besar pula tanggung jawab pemda untuk menyampaikan informasi kepada publik. Penelitian Pratama, Sriwerastuti, dan Sujana (2015) menunjukkan bahwa PAD yang menjadi proksi kekayaan daerah pada penelitiannya berpengaruh terhadap pelaporan keuangan pemerintah daerah. Demikian halnya dengan penelitian Jaya dan Sisdyani (2014) yang menunjukkan bahwa PAD berpengaruh terhadap kelengkapan pengungkapan informasi keuangan daerah melalui situs resmi pemerintah provinsi. Selain itu, dana perimbangan khususnya dana alokasi umum berpengaruh terhadap pengungkapan informasi keuangan daerah melalui situs resmi pemerintah provinsi (Jaya dan Sisdyani, 2014).

H1: Pendapatan daerah berpengaruh terhadap internet financial reporting pemda

Berbagai bentuk belanja daerah baik belanja langsung maupun tidak langsung serta belanja untuk urusan wajib pemerintahan dan urusan pilihan memiliki tujuan yang sama yakni untuk meningkatkan kualitas kehidupan masyarakat, memberikan pelayanan yang baik kepada masyarakat serta memberikan fasilitas yang layak kepada publik. Semakin tinggi belanja daerah seharusnya menunjukkan bahwa pemerintah daerah telah menggunakan anggaran untuk 
kepentingan publik artinya semakin tinggi pula keinginan pemerintah untuk menyampaikan laporan keuangannya kepada publik (Pratama, Sriwerastuti, \& Sujana, 2015). Penelitian Pratama, Sriwerastuti, dan Sujana (2015) menunjukkan bahwa belanja daerah berpengaruh terhadap pelaporan keuangan melalui internet. Sehingga, hipotesis penelitian ini adalah:

H2 : Belanja Daerah berpengaruh terhadap Internet Financial Reporting Pemda

Undang-Undang No. 15 Tahun 2004 dalam Pasal 21 menyatakan bahwa legislatif memiliki hak untuk meminta pemerintah daerah menindaklanjuti hasil pemeriksaan BPK. Semakin besar jumlah anggota legislatif diharapkan berbanding lurus dengan kualitas laporan keuangan yang dilaporkan oleh pemda dan semakin mendorong keinginan pemda untuk melakukan pelaporan keuangan pemda melalui internet. Penelitian Setyaningrum dan Syafitri (2012) menunjukkan bahwa ukuran legislatif yang diukur dengan jumlah anggota DPRD berpengaruh terhadap pengungkapan laporan keuangan.

H3 : Jumlah Anggota DPRD berpengaruh terhadap Internet Financial Reporting Pemda

Menurut Trisnawaty dan Achmad (2014) pemda yang berukuran besar memerlukan pengawasan dan kebutuhan pelaporan yang lebih besar serta harus menanggung biaya pengawasan dan biaya pelaporan yang lebih tinggi. Semakin besar jumlah penduduk maka semakin besar pula biaya yang harus dikeluarkan untuk menyampaikan informasi secara merata dengan tujuan menghindari terjadinya asimetri informasi.

Dengan adanya internet diharapkan informasi dapat disampaikan secara merata kepada seluruh penduduk. Penelitian Hilmi dan Martani (2012), serta penelitian Pratama, Sriwerastuti, dan Sujana (2015) menunjukkan bahwa jumlah penduduk berpengaruh terhadap pengungkapan laporan keuangan.

H4 : Jumlah Penduduk berpengaruh terhadap Internet Financial Reporting Pemda

Akuntansi dan pelaporan merupakan tahap penting dalam akuntabilitas (Mahmudi, 2011). Laporan keuangan daerah merupakan bagian dari pelaporan keuangan (Bastian, 2006). Menurut Peraturan Pemerintah No. 71 tentang Standar Akuntansi Pemerintahan, akuntabilitas merupakan kepentingan pertama pemda dalam melakukan pelaporan keuangan. Artinya, dengan adanya tuntutan dari perundang-undangan dan peraturan pemerintah untuk melaporkan secara terbuka (terlaksananya tranparansi) pemda semakin terdorong untuk meningkatkan akuntabilitas laporan keuangan yang dilaporkan. Fontanella dan Rossieta (2014), mengukur akuntabilitas dari opini laporan keuangan dan opini wajar tanpa pengecualian merupakan opini yang menunjukkan tingkat akuntabilitas pelaporan keuangan yang tinggi.

Penelitian Do, Davey, dan Coy (2014) menunjukkan bahwa dengan adanya pelaporan melalui internet dapat mendorong pemerintah daerah untuk melalukan berbagai usaha untuk meningkatkan akuntabilitasnya karena pemerintah harus mempersiapkan laporan keuangan beberapa bulan sebelum tanggal pelaporan dan melakukan audit atas laporan keuangan yang akan dilaporkan kepada publik. Berdasarkan uraian tersebut, rumusan hipotesis penelitian ini adalah:

H5: Internet Financial Reporting Pemda berpengaruh terhadap akuntabilitas laporan keuangan daerah

\section{METODE PENELITIAN \\ Populasi dan Sampel}

Populasi pada penelitian ini adalah seluruh Pemerintah Provinsi di Indonesia. Sampel dalam penelitian sebanyak 96 observasi dari 32 provinsi dari tahun 2012-2014. Kalimantan Utara dan Maluku Utara dihapus dalam pemilihan sampel. Hal ini dikarenakan Kalimantan Utara merupakan provinsi yang baru terbentuk di tahun 2014, sedangkan situs resmi provinsi Maluku Utara tidak dapat diakses karena sedang dalam tahap pengembangan.

\section{Jenis dan Sumber Data}

Data pada penelitian ini merupakan data 
sekunder. Variabel internet financial reporting pemda diperoleh dengan mengakses situs resmi atau website pemda. Data terkait pendapatan daerah dan belanja daerah diperoleh dari situs resmi Direktorat Jenderal Keuangan Daerah untuk data tahun 2013 dan 2014 dan situs resmi Direktorat Jenderal Perimbangan Keuangan untuk data tahun 2012. Data terkait opini audit diperoleh dari Indeks Hasil Pemeriksaan Semester 1 tahun 2015 oleh BPK. Jumlah Penduduk diperoleh melalui situs resmi Badan Pusat Statistik (BPS). Untuk data jumlah penduduk tahun 2012, berdasar pada data terakhir yakni data jumlah penduduk pada tahun 2010. Selain itu, situs resmi DPRD setiap provinsi dan situs resmi komisi pemilihan umum merupakan sumber data jumlah anggota DPRD setiap provinsi. Pengukuran variabel penelitian dapat dilihat pada Tabel 1 .

\section{Teknik Analisis Data}

Teknik analisis yang digunakan adalah regresi logistik karena variabel dependen merupakan variabel dikotomik. Implikasi internet financial reporting pada akuntabilitas laporan keuangan daerah menggunakan teknik analisis regresi logistik ordinal (Ordinal Logistic Regression).

Secara umum, persamaan regresi logistik adalah sebagai berikut:

$$
\begin{gathered}
\operatorname{Ln} \frac{p}{1-p}=b 0+b 1 X 1+b 2 X 2+b 3 X 3+b 4 X 4 \text {..(1) } \\
\text { Ln } \frac{p}{1-p} \text { Adalah internet financial re- }
\end{gathered}
$$
porting pemda (Y). b0 adalah konstanta. X1 adalah pendapatan daerah. X2 adalah belanja daerah. X3 adalah jumlah anggota DPRD. X4 adalah jumlah penduduk. b1,b2,b3 dan b4 adalah koefisien regresi.

Selain itu, persamaan regresi logistik ordinal adalah sebagai berikut:

$$
\begin{aligned}
& \text { Logit }(\mathrm{p} 1)=\alpha 1+\beta^{\prime} Y \\
& \text { Logit }(\mathrm{p} 1+\mathrm{p} 2)=\alpha 1+\beta^{\prime} Y \\
& \text { Logit }(\mathrm{p} 1+\mathrm{p} 2+\mathrm{p} 3)=\alpha 1+\beta^{\prime} Y \\
& \text { Logit }(\mathrm{p} 1+\mathrm{p} 2+\mathrm{p} 3+\mathrm{p} 4)=\alpha 1+\beta^{\prime} Y \\
& \text { Logit }(\mathrm{p} 1+\mathrm{p} 2+\mathrm{p} 3+\mathrm{p} 4+\mathrm{p} 5)=\alpha 1+\beta^{\prime} Y . .(2)
\end{aligned}
$$

Logit $(\mathrm{p} 1+\ldots+\mathrm{p} 5)$ adalah akuntabilitas laporan keuangan daerah. P1 adalah probabilitas tidak memberikan pendapat. P2 adalah probabilitas tidak wajar. P3 adalah probabilitas wajar dengan pengecualian. P4 adalah probabilitas wajar tanpa pengecualian dengan paragraf penjelas. P5 adalah robabilitas wajar tanpa pengecualian $\beta$ ' adalah koefisien regresi. Y adalah internet financial reporting pemda

\begin{tabular}{|c|c|c|}
\hline $\begin{array}{c}\text { Variabel } \\
\text { Penelitian }\end{array}$ & Pengukuran & Skala \\
\hline Internet Financial & Jika pemda melaporkan laporan keuangan di internet & \\
\hline $\begin{array}{l}\text { Reporting pemda } \\
\text { (Y) }\end{array}$ & $\begin{array}{l}\text { maka diberi angka "1", apabila tidak melaporkan maka } \\
\text { diberi angka "0" }\end{array}$ & Nominal \\
\hline Pendapatan Dae- & Ln Total Pendapatan Daerah & Rasio \\
\hline Belanja Daerah & Ln Total Belanja Daerah & Rasio \\
\hline $\begin{array}{l}\text { Jumlah Anggota } \\
\text { DPRD (X3) }\end{array}$ & Jumlah Anggota DPRD terpilih pada tahun 2012-2014 & Rasio \\
\hline $\begin{array}{l}\text { Jumlah } \\
\text { Penduduk (X4) }\end{array}$ & $\begin{array}{l}\text { Kepadatan Penduduk per } \mathrm{km}^{2} \text { dikalikan dengan luas wila- } \\
\text { yah daerah }\end{array}$ & Rasio \\
\hline Akuntabilitas & Opini audit, yaitu & \\
\hline \multirow{3}{*}{$\begin{array}{l}\text { Laporan Keu- } \\
\text { angan Daerah (Z) }\end{array}$} & (1) Tidak Memberikan Pendapat (TMP) & \\
\hline & (2) Tidak Wajar (TW), (3) Wajar Dengan Pengecualian (WDP) & \\
\hline & $\begin{array}{l}\text { (4) Wajar Tanpa Pengecualian dengan Paragraf Penjelas } \\
\text { (WTP-DPP) } \\
\text { (5) Wajar Tanpa Pengecualian (WTP) }\end{array}$ & Ordinal \\
\hline
\end{tabular}

Pengujian yang dilakukan dalam model regresi logistik adalah meliputi uji Hosmer and Lemeshow Test, overall model fit, Omnibus test of model, dan Nagelkerke

Tabel 1.

Pengukuran Variabel Penelitian 
$R$ Square. Selain itu, pengujian yang dilakukan model regresi logistik ordinal adalah meliputi uji nilai -2 Log Likelihood (model fitting information), goodness of fit berdasarkan nilai signifikansi pearson, test of parallel lines, dan Nagelkerke R Square.

\section{ANALISIS DAN PEMBAHASAN \\ Statistik Deskriptif}

Berdasarkan data yang telah diperoleh, pemda yang melakukan Internet Financial Reporting mengalami peningkatan dari tahun ke tahun. Internet Financial Reporting pemda pada tahun 2014 sebesar 68.8\% dan merupakan perentase tertinggi dibandingkan dua tahun sebelumnya. Tahun 2012 merupakan persentase terendah karena hanya 37,5 \% Pemerintah Provinsi di Indonesia yang melakukan Internet Financial Reporting. Akuntabilitas laporan keuangan daerah yang diukur dengan opini menunjukkan bahwa opini wajar tanpa pengecualian memiliki persentase tertinggi yakni $35,4 \%$ sedangkan opini dengan persentase terendah adalah opini tidak memberikan pendapat dengan persentase $6,3 \%$.

Hasil statistik deskriptif ditunjukkan pada tabel 2. variabel Internet Financial Reporting pemda memiliki nilai rata-rata (mean) sebesar 0,55 dan nilai simpangan baku (standard deviation) sebesar 0,500. Nilai terendah adalah 0 , sedangkan nilai tertinggi adalah 1 . Variabel pendapatan daerah Pemerintah Provinsi di Indonesia tahun anggaran 2012-2014 memiliki nilai rata-rata (mean) 29,0658 dan nilai simpangan baku (standard deviation) 0.86908. Nilai minimum adalah 27.56 (Gorontalo) sedangkan nilai maksimum adalah 31.40 (DKI Jakarta). Variabel belanja daerah memiliki nilai rata-rata (mean) 28,9999 dan nilai simpangan baku

Tabel 2.

Hasil Statistik Deskriptif

\begin{tabular}{|c|c|c|c|c|c|}
\hline & $\mathbf{N}$ & Min & $\operatorname{Max}$ & Mean & Std. Dev \\
\hline $\mathrm{Y}$ & 96 & 0 & 1 & 0,55 & 0,500 \\
\hline LnX1 & 96 & 27,56 & 31,40 & 29,07 & 0,869 \\
\hline LnX2 & 96 & 27,49 & 31,30 & 28,99 & 0,864 \\
\hline X3 & 96 & 44 & 106 & 61,99 & 19,739 \\
\hline LnX4 & 96 & 18.09 & 17,87 & 15,28 & 1,086 \\
\hline Z & 96 & 1 & 5 & 3,83 & 1,111 \\
\hline $\begin{array}{l}\text { Valid N } \\
\text { (listwise) }\end{array}$ & 96 & & & & \\
\hline
\end{tabular}

(standard deviation) 0.86351. Nilai minimum adalah 27,49 (Sulawesi Barat) sedangkan nilai maksimum adalah 31.30 (DKI Jakarta). Variabel jumlah anggota DPRD Pemerintah Provinsi di Indonesia tahun 2012-2014 memiliki nilai rata-rata (mean) 61,99 dan nilai simpangan baku (standard deviation) 19,739. Nilai minimum adalah 44 (Papua) sedangkan nilai maksimum adalah 106 (DKI Jakarta). Variabel jumlah penduduk memiliki nilai rata-rata (Mean) 15,2830 dan simpangan baku (standard deviation) 1,08601. Nilai minimum adalah 13,09 (Jawa Timur), sedangkan nilai maksimum adalah 17,87 (Gorontalo).

\section{Kelayakan Model Regresi Logistik dan Regresi Logistik Ordinal}

Langkah pertama yang dilakukan dalam analisis regresi logistik dan regresi logistik ordinal adalah menilai kelayakan model regresi. Tabel 3 menunjukkan bahwa nilai signifikansi Hosmer and Lemeshow Test adalah 0,879 , lebih dari 5\% artinya, model regresi layak atau dapat diterima. Tabel 4 menunjukkan adanya penurunan nilai -2 Log Likelihood, pada block number $=0$ adalah 132,041 sedangkan nilai -2 Log Likelihood pada block number $=1$ adalah 120,234. Tabel 5 menunjukkan hasil Omnibus tests of model, tingkat signifikansi berada dibawah 5\% atau 0,05 yang menunjukkan bahwa variabel bebas yang

Tabel 3.

Hosmer and Lemeshow Test

\begin{tabular}{lrrr}
\hline Step & Chi-Square & df & Sig. \\
\hline 1 & 3,748 & 8 & 0,879 \\
\hline
\end{tabular}

Tabel 4.

Overall Model Fit

\begin{tabular}{cc}
\hline Iteration History & $\mathbf{- 2}$ Log Likelihood \\
\hline Step 0 & 132,041 \\
Step 1 & 120,234 \\
\hline
\end{tabular}

Tabel 5.

Omnibus Tests of Model

\begin{tabular}{llrrr}
\hline & & Chi-Square & df & Sig. \\
\hline Step 1 & Step & 12,018 & 4 & 0,17 \\
& Block & 12,018 & 4 & 0,17 \\
& Model & 12,018 & 4 & 0,17 \\
\hline
\end{tabular}


digunakan secara bersama-sama berpengaruh terhadap internet financial reporting pemda atau minimal salah satu variabel yang digunakan dalam penelitian berpengaruh terhadap internet financial reporting pemda. Tabel 6 menunjukkan nilai Nagelkerke $R$ Square yakni sebesar 0,157 artinya $15,7 \%$ variabel internet financial reporting pemda dipengaruhi oleh variabel independen yaitu pendapatan daerah, belanja daerah, jumlah anggota DPRD dan jumlah penduduk. Tabel 7 menunjukkan nilai -2 Log Likelihood regresi logistik ordinal yang mengalami penurunan sebesar 0,326 atau dari 23,175 menjadi 22,849. Akan tetapi penurunan ini tidak begitu signifikan sehingga untuk menilai kelayakan model regresi dapat diketahui pula melalui tabel 8 output goodness of fit regresi logistik ordinal. Nilai signifikansi pearson dan deviance lebih dari 0,05 atau $5 \%$ Nilai signifikansi deviance adalah 0,557. Artinya, nilai signifikansi tersebut lebih dari 0,05 atau

Tabel 6.

Cox \& Snell R Square dan Nagelkerke R Square Regresi Logistik

Cox \& Snell R Square $\quad 0.118$

Nagelkerke R Square $\quad 0.157$

Tabel 7.

Model Fitting Information

\begin{tabular}{cc}
\hline Model & $\begin{array}{c}-2 \\
\text { lihood }\end{array}$ \\
\hline Intercept Only & 23.175 \\
Final & 22.849 \\
\hline
\end{tabular}

Tabel 8.

Goodness Of Fit Regresi Logistik Ordinal

\begin{tabular}{cccc}
\hline & $\begin{array}{c}\text { Chi- } \\
\text { Square }\end{array}$ & Df & Sig. \\
\hline Pearson & 1.153 & 2 & .562 \\
Deviance & 1.169 & 2 & .557 \\
\hline
\end{tabular}

5\%. Dengan demikian, dapat disimpulkan bahwa model regresi fit. Tabel 9 menunjukkan nilai signifikansi test of parallel lines yakni sebesar 0,557. Artinya, nilai signifikansi lebih dari 5\% atau 0.05. Dengan demikian, link function yang dipilih sudah tepat yakni cauchit. Tabel 10 menunjukkan nilai Nagelkerke $R$ Square sebesar 0,004 yang artinya 0,4\% variabel akuntabilitas laporan keuangan daerah dipengaruhi oleh variabel independen yaitu internet financial reporting pemda.

\section{Analisis dan Pembahasan}

Berdasarkan hasil uji regresi logistik yang ditunjukkan oleh tabel 11 maka dapat disusun persamaan regresi logistik sebagai berikut:

$$
\begin{aligned}
& \operatorname{Ln} \frac{p}{1-p}=-11,271-L N 5,727 X 1+L N 5,985 X 2 \\
&-0,031 X 3+L N 0,413 X 4 \quad \ldots \ldots \ldots \ldots . .(3) \\
& \text { Ln } \frac{p}{1-p} \text { adalah internet financial re- }
\end{aligned}
$$
porting pemda. LNX1 adalah LN pendapatan daerah. LNX2 adalah LN belanja daerah. X3 adalah jumlah anggota DPRD. LNX4 adalah jumlah penduduk.

Koefisien regresi variabel pendapatan daerah adalah -5.727 dan tingkat signifikansi variabel pendapatan daerah adalah 0,006, lebih kecil dari 5\% atau 0,05.

\begin{tabular}{|c|c|c|c|c|}
\hline Model & $\begin{array}{c}-2 \text { Log } \\
\text { Likelihood }\end{array}$ & $\begin{array}{c}\text { Chi- } \\
\text { Square }\end{array}$ & df & Sig. \\
\hline $\begin{array}{l}\text { Null } \\
\text { Hypothesis }\end{array}$ & 22,849 & & & \\
\hline General & 21,680 & 1.169 & 2 & 0,557 \\
\hline
\end{tabular}

Tabel 9.

Test of Parallel Lines

Tabel 10.

Cox \& Snell R Square dan Nagelkerke $R$ Square Regresi Logistik Ordinal

Cox \& Snell R Square 0.003

Nagelkerke R Square $\quad 0.004$

\begin{tabular}{|c|c|c|c|c|c|c|c|}
\hline & & B & S.E & Wald & df & Sig. & Exp(B) \\
\hline \multirow{5}{*}{ Step $1^{\mathrm{a}}$} & $\operatorname{LnX1}$ & $-5,727$ & 2,091 & 7,504 & 1 & 0,006 & 0,003 \\
\hline & $\operatorname{LnX} 2$ & 5,985 & 2,080 & 8,281 & 1 & 0,004 & 379,603 \\
\hline & X3 & $-0,031$ & 0,022 & 2,021 & 1 & 0,155 & 0,969 \\
\hline & $\operatorname{LnX} 4$ & 0,413 & 0,346 & 1,422 & 1 & 0,233 & 1,511 \\
\hline & Constant & $-11,271$ & 11,063 & 1,038 & 1 & 0,308 & 0,000 \\
\hline
\end{tabular}

Tabel 11.

Hasil Uji Regresi Logistik 
Artinya, variabel pendapatan daerah yang di ukur dengan LN pendapatan daerah berpengaruh negatif terhadap internet financial reporting pemda. Hasil penelitian ini menunjukkan bahwa kenaikan pendapatan daerah tidak mendorong keinginan pemda untuk melakukan pelaporan keuangan di internet. Hasil statistik deskriptif menunjukkan nilai rata-rata (mean) dari variabel pendapatan daerah adalah 29,0658 dan standar deviasinya adalah 0,86908 . Hal ini menunjukkan bahwa data pendapatan daerah sangat bervariasi. Selain itu, Internet financial reporting yang dilakukan oleh pemda tidak bergantung pada kenaikan pendapatan daerah melainkan pada rasa tanggung jawab pemda untuk melakukan transparansi informasi keuangan serta mematuhi peraturan perundang-undangan maupun peraturan pemerintah.

Koefisien regresi belanja daerah sebesar 5,985 dan nilai signifikansi variabel belanja daerah adalah 0,004, lebih kecil dari $5 \%$ atau 0,05 . Artinya, variabel belanja daerah yang di ukur dengan LN belanja daerah berpengaruh positif terhadap internet financial reporting pemda. Pemda yang melakukan internet financial reporting menunjukkan bahwa anggaran belanja daerah telah digunakan sesuai dengan aturan yang berlaku. Selain itu, menurut teori legitimasi pemda yang melakukan internet financial reporting dapat membangun persepsi pihak eksternal bahwa anggaran belanja telah digunakan untuk memenuhi kebutuhan pemda untuk menyelenggarakan pemerintahan dan memenuhi kebutuhan masyarakat dalam rangka meningkatkan kualitas kehidupan masyarakat daerah tersebut.

Koefisien regresi variabel jumlah ang- gota DPRD adalah -0,031 dan nilai signifikansi variabel jumlah anggota DPRD adalah 0,155, lebih besar dari 5\% atau 0,05. Artinya, variabel jumlah anggota DPRD tidak berpengaruh terhadap internet financial reporting pemda. Hal ini menunjukkan bahwa semakin besar jumlah anggota DPRD tidak mendorong keinginan pemda untuk meakukan internet financial reporting. Hasil analisis statistik deskriptif menunjukkan nilai rata-rata dari variabel jumlah anggota DPRD adalah 61,99 dan standar deviasinya 19,739. Artinya dengan standar deviasi jumlah anggota DPRD tersebut, jumlah anggota DPRD setiap daerah sangat bervariasi.. Faktor tersebut adalah anggota DPRD belum mampu melakukan pengawasan yang optimal terhadap penyelenggaraan pemerintahan (Hanapiah, 2011).

Koefisien regresi variabel jumlah penduduk adalah 0,413 dan nilai signifikansi variabel jumlah penduduk yang diukur dengan LN jumlah penduduk adalah 0,233, lebih besar dari $5 \%$ atau 0,05 . Artinya, variabel jumlah penduduk tidak berpengaruh terhadap internet financial reporting pemda atau semakin besarnya jumlah penduduk di suatu daerah tidak mendorong keinginan pemda untuk melakukan internet financial reporting. Hasil analisis statistik deskriptif menunjukkan bahwa nilai rata-rata variabel jumlah penduduk yang diukur dengan LN jumlah penduduk adalah 15,2830 dan standar deviasinya adalah 1,08601 . Nilai kenaikan rata-rata jumlah penduduk dapat dikatakan besar dan seharusnya berbanding lurus dengan keinginan pemda untuk melakukan internet financial reporting. Akan tetapi, besarnya variasi data jumlah penduduk menyebabkan jumlah penduduk tidak

Tabel 12.

Hasil Uji Regresi Logistik Ordinal

\begin{tabular}{|c|c|c|c|c|c|c|c|c|}
\hline & & \multirow{2}{*}{$\begin{array}{l}\text { Esti- } \\
\text { mate }\end{array}$} & \multirow{2}{*}{$\begin{array}{l}\text { Std. } \\
\text { Error }\end{array}$} & \multirow{2}{*}{ Wald } & \multirow{2}{*}{ df } & \multirow{2}{*}{ Sig. } & \multicolumn{2}{|c|}{$\begin{array}{l}\text { 95\% Confidence } \\
\text { Interval }\end{array}$} \\
\hline & & & & & & & $\begin{array}{l}\text { Lower } \\
\text { Bound }\end{array}$ & $\begin{array}{l}\text { Upper } \\
\text { Bound }\end{array}$ \\
\hline \multirow[t]{3}{*}{ Threshold } & [OPINI=1] & $-0,5064$ & 2,017 & 6,305 & 1 & 0,012 & $-9,017$ & $-1,111$ \\
\hline & [OPINI=3] & $-0,419$ & 0,232 & 3,265 & 1 & 0,071 & $-0,873$ & 0,035 \\
\hline & [OPINI=4] & 0,420 & 0,232 & 3,258 & 1 & 0,071 & $-0,036$ & 0,875 \\
\hline \multirow[t]{2}{*}{ Location } & [IFR_PEMDA=0] & $-0,184$ & 0,320 & 0,328 & 1 & 0,567 & $-0,812$ & 0,445 \\
\hline & [IFR_PEMDA=1] & $0^{\mathrm{a}}$ & & $\cdot$ & 0 & . & . & ${ }^{\circ}$ \\
\hline
\end{tabular}


dapat mendorong keinginan pemda untuk melakukan internet financial reporting.

Berdasarkan hasil uji regresi logistik ordinal pada tabel 12 diperoleh persamaan regresi sebagai berikut:

$$
\text { Cauchit }(\mathrm{p} 1)=-5,064-0,184 \mathrm{Y}
$$

Cauchit $(\mathrm{p} 1+\mathrm{p} 3)=-5,419-0,184 \mathrm{Y}$

Cauchit $(\mathrm{p} 1+\mathrm{p} 3+\mathrm{p} 4)=0,420-0,184 \mathrm{Y}$.

Cauchit $(\mathrm{p} 1+\mathrm{p} 3+\mathrm{p} 4)$ adalah akuntabilitas laporan keuangan daerah. P1 adalah probabilitas tidak memberikan pendapat. P3 adalah probabilitas wajar dengan pengecualian. P4 adalah probabilitas wajar tanpa pengecualian dengan paragraf penjelas. Y adalah internet financial reporting pemda

Adapun koefisien regresi adalah 0,184 dan nilai signifikansi variabel Internet Financial Reporting yang diukur dengan opini adalah 0,567 , lebih besar dari $5 \%$ atau 0,05 . Artinya, hipotesis 5 ditolak dan variabel internet financial reporting pemda tidak berpengaruh terhadap Akuntabilitas Laporan Keuangan Daerah. Hasil penelitian ini menunjukkan, walaupun pemda telah melakukan internet financial reporting dan telah diwajibkan untuk menyampaikan informasi keuangan secara terbuka serta akuntabel, belum mampu mendorong keinginan pemda untuk meningkatkan akuntabilitas laporan keuangan daerahnya.

\section{SIMPULAN}

Berdasarkan hasil pengujian pada beberapa hipotesis pada penelitian ini maka dapat disimpulkan bahwa Variabel pendapatan daerah yang diukur dengan LN pendapatan daerah, jumlah anggota DPRD, dan jumlah penduduk yang diukur dengan LN jumlah penduduk tidak berpengaruh terhadap internet financial reporting pemda. Sedangkan, variabel belanja daerah yang diukur dengan LN belanja daerah berpengaruh terhadap internet financial reporting pemda. Selain itu, variabel internet financial reporting pemda tidak berpengaruh terhadap akuntabilitas laporan keuangan daerah.

Hasil penelitian ini memberikan bukti empiris tambahan dan referensi dalam bidang akuntansi sektor publik terkait inter- net financial reporting pemda. Selain itu, penelitian ini turut memberikan referensi tambahan mengenai implikasi internet financial reporting pemda terhadap akuntabilitas laporan keuangan daerah. Penelitian ini memberikan gambaran kepada pemda bahwa internet financial reporting merupakan salah satu cara pemda untuk melakukan transparansi atas informasi keuangan serta menunjukkan pemda telah menjalankan pemerintahan sesuai dengan aturan yang berlaku.

\section{KETERBATASAN DAN SARAN Keterbatasan}

Penelitian ini masih memiliki beberapa keterbatasan. Penelitian ini hanya menggunakan pemerintah provinsi di Indonesia dengan periode pelaporan 2012-2014 karena adanya kendala untuk memperoleh data yang diinginkan peneliti. Selain itu, masih banyak faktor yang dapat digunakan untuk menjelaskan faktor-faktor yang berpengaruh terhadap internet financial reporting pemda dan kaitannya dengan akuntabilitas laporan keuangan.

\section{Saran}

Penelitian selanjutnya sebaiknya menambah pemerintah kabupaten/kota sebagai sampel penelitian dan menambah variabel lain seperti dari sisi informasi yang disajikan di neraca dan laporan perubahan ekuitas, latar belakang pendidikan anggota DPRD dan penduduk, tekanan media massa dan jumlah pengguna internet disetiap daerah. Bagi pemda yang tidak melakukan internet financial reporting sebaiknya diberikan teguran, peringatan, atau sanksi yang tegas karena telah melanggar peraturan perundang-undangan yakni UndangUndang No.14 Tahun 2008 tentang Keterbukaan Informasi Publik dan Peraturan Pemerintah No.65 Tahun 2010 tentang Sistem Informasi Keuangan Daerah. Sanksi tersebut dapat berupa pengurangan anggaran yang diberikan kepada pemda. Kedepannya, opini wajar tanpa pengecualian menjadi syarat pemda untuk melakukan internet financial reporting.

DAFTAR PUSTAKA

Afryansyah, R.D., \& Haryanto. (2013). 
Faktor-faktor yang mempengaruhi pengungkapan informasi akuntansi di internet oleh pemerintah daerah. Diponegoro Journal of Accounting, 2 (3), 1-11.

Bastian, I. (2006). Akuntansi Sektor Publik. Jakarta: Penerbit Erlangga.

Damaso, M.G., \& Lourenco, I.C. (2001). Legitimacy theory and internet financial reporting. Santarem, Portugal. Working Paper, ESGTS School of Management and Technology.

Do, S. J., Davey, H., \& Coy, D. (2014). Assessing accountability of organizations using the internet to report: South Korean local government. Journal of Finance and Management in Public Services, 12(1), 1-26.

Fontanella, A. \& Rossieta, H. (2014). Pengaruh desentralisasi fiskal dan kinerja terhadap akuntabilitas pelaporan keuangan pemerintah daerah di Indonesia. Paper dipresentasikan pada acara Simposium Nasional Akuntansi XVII, Lombok.

Government Finance Officers Association. (2009). Presenting official financial documents on your government's website. GFOA. Chicago.

Hanapiah, A. (2011). Optimalisasi pelaksanaan fungsi pengawasan dewan perwakilan rakyat daerah dalam penyelenggaraan pemerintahan. Jurnal Institut Pemerintahan Dalam Negeri, 1-16.

Hilmi, A.Z., \& Martani, D. (2012). Analisis faktor-faktor yang mempengaruhi tingkat pengungkapan laporan keuangan pemerintah provinsi. Paper dipresentasikan pada acara Simposium Nasional Akuntansi XV, Banjarmasin.

Jaya, J. D., \& Sisdyani, E. A. (2014). Pengaruh pendapatan asli daerah, dana alokasi umum, dan belanja modal pada kelengkapan pengungkapan informasi keuangan daerah melalui situs resmi pemerintah provinsi. E-Jurnal Akuntansi Udayana, 9(1), 162-179.

Mahmudi. (2011). Akuntansi sektor publik. Yogyakarta: UII Press.

Mahsun, Sulistiyowati, F., \& Purwanugraha, H.A. (2012). Akuntansi sektor publik (Edisi ketiga). Yogyakarta: BPFE.

Pratama, K.A., Sriwerastuti, D.N., \& Sujana, E. (2015). Pengaruh kompleksitas pemerintah daerah, ukuran pemerintah daerah, kekayaan daerah, dan belanja daerah terhadap pelaporan keuangan pemerintah daerah. Jurnal Ilmiah Mahasiswa Akuntansi Undiksha, 3(1).

Peraturan Pemerintah Nomor 56 tahun 2005. Sistem informasi keuangan daerah. 12 September 2005. Lembaran Negara Republik Indonesia Nomor 4576. Jakarta.

Peraturan Pemerintah Nomor 65 tahun 2010. Perubahan peraturan pemerintah no. 56 tahun 2005 tentang sistem informasi keuangan daerah. 30 Agustus 2010 Lembaran Negara Republik Indonesia Nomor 5155. Jakarta.

Peraturan Pemerintah Nomor 71 tahun 2010 . Standar akuntansi pemerintahan. 22 Oktober 2010. Lembaran Negara Republik Indonesia Nomor 5165. Jakarta.

Setyaningrum, D., \& Syafitri, F. (2012). Analisis pengaruh karakteristik pemerintah daerah terhadap tingkat pengungkapan laporan keuangan. Jurnal Akuntansi dan Keuangan Indonesia, 9(2), 154-170.

Suchman, M.C. (1995). Managing legitimacy: Strategic and institutional approaches. Academy of management review, 20(3), 571-610.

Trisnawati, M. D., \& Achmad, K. (2014). Determinan publikasi laporan keuangan pemerintah daerah melalui internet. Paper dipresentasikan pada acara Simposium Nasional Akuntansi XVII, Manado.

Undang-undang Republik Indonesia Nomor 17 Tahun 2003. Keuangan negara. 5 April 2003. Lembaran Negara Republik Indonesia Tahun 2003 Nomor 4286. Jakarta.

Undang-Undang Republik Indonesia Nomor 15 Tahun 2004. Pemeriksaan pengelolaan dan tanggung jawab keuangan negara. 19 Juli 2004. Lembaran Negara Republik Indonesia Tahun 2004 Nomor 4400. Jakarta.

Undang-Undang Republik Indonesia Nomor 14 tahun 2008. Keterbukaan informasi publik. 30 April 2008. Lembaran Negara Republik Indonesia Tahun 2008 Nomor 4846. Jakarta.

Verawaty, V. (2015). Determinan aksesibilitas internet financial reporting melalui e-government pemerintah daerah di Indonesia. Paper dipresentasikan pada acara Simposium Nasional Akuntansi XVIII, Medan. 